\title{
Preparation and characterization of nanocrystalline titania powders by sonochemical synthesis
}

\author{
Özlem Çağlar Duvarci *, Muhsin Çiftçioğlu \\ Chemical Engineering Department, Izmir Institute of Technology, Urla, IZMIR, Turkey
}

\section{A R T I C L E I N F O}

\section{Article history:}

Received 9 October 2011

Received in revised form 27 March 2012

Accepted 7 May 2012

Available online 12 May 2012

\section{Keywords:}

Nanocrystalline titania

Precipitation

Ultrasonic treatment

Sintering

Shrinkage curve

\begin{abstract}
A B S T R A C T
Nanocrystalline mesoporous titania powders were synthesized by hydrolyzing titanium isopropoxide in ethanol-water mixtures which were ultrasonically treated without using any templates or chemicals. Titanium isopropoxide-ethanol mixture was added dropwise to a water-ethanol mixture placed in an ultrasonic bath. The properties of the sonochemically synthesized powder were compared with those of the powders prepared without ultrasonic treatment along with Degussa P-25 titania powder. The phase structure, crystallite size, surface area, particle size, powder density were determined and sintering behavior was analyzed in this work. The nanotitania powder prepared during ultrasonic induced hydrolysis $\left(\mathrm{TiO}_{2}-\mathrm{U}\right)$ was determined to be formed from a mixture of anatase and brookite phases at $25{ }^{\circ} \mathrm{C}$. The brookite phase in nanotitania powder prepared without ultrasonic treatment $\left(\mathrm{TiO}_{2}-\mathrm{NoU}\right)$ was detected at $70^{\circ} \mathrm{C}$. The anatase-rutile phase transformation was completed in the $500-700{ }^{\circ} \mathrm{C}$ range for both powders. The average crystallite sizes of the powders at $25{ }^{\circ} \mathrm{C}$ were determined as 10 and $5 \mathrm{~nm}$ for $\mathrm{TiO}_{2}-\mathrm{NoU}$ and $\mathrm{TiO}_{2}-\mathrm{U}$, respectively. The surface area decreased from 238 to $106 \mathrm{~m}^{2} / \mathrm{g}_{\text {for TiO}}$ NoU and from 287 to $82 \mathrm{~m}^{2} / \mathrm{g}$ for $\mathrm{TiO}_{2}-\mathrm{U}$ when the calcination temperature was increased from 200 to $500{ }^{\circ} \mathrm{C}$. The evolution of the $\mathrm{N}_{2}$ adsorption-desorption behavior with calcination temperature and the corresponding pore size distributions/volumes was attributed to the formation of closely packed submicron aggregates during powder synthesis and calcination. The sintering behavior was concluded to be controlled by 7-10 nm crystallites and the submicron aggregates. The determination of the densification behavior of titania powders prepared by different methods with various levels of dopants may prove to be very useful for a better understanding of the phase/pore structure evolution which is crucial for a significant number of applications.
\end{abstract}

(c) 2012 Elsevier B.V. All rights reserved.

\section{Introduction}

The emergence of nanomaterials had a great impact on several domains of science and technology such as chemistry, electronics, biotechnology, etc. Numerous applications based on optical, electrical, magnetic, catalytic, biological, or mechanical properties of nanomaterials originate from their unique and finely tunable nanostructures which make their synthesis one of the most promising and challenging research and development areas.

Establishing the relations between performance of the final product and the properties of the precursors and powders, their processing conditions, and the production rates necessitates a delicate continuous effort. The large scale production of starting precursors and nanomaterials with desired properties may accelerate the realization of the potential applications especially towards the supply of novel solutions to the cumulative need for sustainable clean energy and environmental pollution problems facing mankind.

\footnotetext{
* Corresponding author.

E-mail addresses: ozlemduvarci@iyte.edu.tr (Ö.Ç. Duvarci), muhsinciftcioglu@iyte.edu.tr (M. Çiftçioğlu).
}

Nanopowders/nanomaterials with novel physical, chemical, and mechanical properties can be utilized as the main building blocks of innovative solutions to the problems in energy, environment, health, communication and related areas. The functionality of a nanomaterial may rely on the surface area to volume ratio because the interactions with the surrounding media strongly depend on the extent of the surface area and the nature of the material surface.

Nanotitania gained considerable attention due to its potential and current uses such as ceramics [1], hydrogen [2] and carbon monoxide [3] gas sensors, catalytic and photocatalytic applications [4-7] including medicine, environmental cleaning [8,9], disinfection [10,11], hydrogen production from water [12], artificial photosynthesis [13,14] and thin film applications for solar cells and self-cleaning/antibacterial/ hydrophilic surfaces [15].

Preparation methods and conditions have a great influence on the properties of titania powders such as size, shape, phase/pore structure, surface properties and phase transformations [16]. High surface area nanoparticles have been produced via ultrasonic irradiation in which the shock waves are capable of rupturing chemical bonds, generating highly reactive chemical species, and increasing mass transfer with particular effects on nucleation/crystal growth during powder preparation. The chemical effects of ultrasonic irradiation are based on acoustic 
cavitation where micro cavities in liquid medium form, grow, and collapse violently in extremely short time periods. The implosive collapse of cavities generates localized regions with high temperatures $(\sim 5000 \mathrm{~K})$ and pressures $(\sim 1000 \mathrm{~atm})$ at high heating/cooling rates $\left(>10^{10} \mathrm{~K} / \mathrm{s}\right.$ ) which are called hot spots [17-20]. The cavities (bubbles) contain vapor generated from either the liquid medium or the dissolved volatile gas/reagents. The vapor is subjected to high temperatures and pressures on collapse of the bubbles and results in molecular fragmentation with generation of highly reactive chemical species. These species might be $\mathrm{H} \bullet, \mathrm{OH} \bullet$ and even $\mathrm{H}_{2} \mathrm{O}_{2}$ for water. The evolution of the bubbles causes impingements on the surfaces producing erosion at and around the point of impact, causes the removal of particles from the surface and disorganizes the surface thus creating local defects, dislocations, and vacancies at the solid-liquid interface [21].

Ultrasonic irradiation can be applied during or after precipitation of titanium salt/alkoxide precursors in water or ethanol-water mixtures. Investigations on the application of ultrasonic treatment after precursor mixing have shown that secondary phase formation and crystallite size of the powders were dependent on the ethanolwater ratio and duration of ultrasonic irradiation [22-24]. It was reported that the brookite phase formation ceased and the nature of the precipitates were no longer amorphous with decreasing ethanol-water ratio. The prolonged ultrasonic irradiation time was also observed to reduce the crystallite size of titania powders in the above studies.

The addition of precursor (titanium isopropoxide-TIP or titanium tetrachloride-TTC) into water or ethanol-water mixture by injection was also investigated [25]. The temperature of the mixture reached $100{ }^{\circ} \mathrm{C}$ when ultrasonic treatment was terminated. The final phases of the powders were determined as being amorphous, anatase, rutile, anatase-rutile or brookite-anatase mixture depending on the precursor composition. The $\mathrm{N}_{2}$ sorption isotherms displayed $\mathrm{H} 2$ and $\mathrm{H} 3$ hysteresis loops indicating that the powders were mesoporous. The largest surface area $\left(290 \mathrm{~m}^{2} / \mathrm{g}\right)$ was obtained from the powder which was recovered from the supernatant of hydrolyzed TIP after centrifugation. The phase structure was reported to depend on precursor composition (TIP/TTC) and reaction temperature. These findings were further explained to be due to the formation of a larger number of seed nuclei in the gel when the precursor was pure TIP.

The dropwise addition of titanium butoxide into water under ultrasonic irradiation caused the formation of micro/mesoporous titania powders [26]. Ultrasonic irradiation led to the formation of a crystalline powder (anatase and brookite mixture), while the powder without ultrasonic treatment was amorphous. The surface area and pore diameter of the powder prepared under ultrasonic irradiation after heat treatment at $100{ }^{\circ} \mathrm{C}$ were $264 \mathrm{~m}^{2} / \mathrm{g}$ and $4.3 \mathrm{~nm}$ respectively.

The dropwise addition of undiluted or ethanol diluted titanium alkoxide into water or ethanol-water mixtures under ultrasonic irradiation was investigated $[27,28]$. It was reported that the application of ultrasonic irradiation facilitated the generation of the secondary phase (brookite) and increase in ethanol to water ratio induced a decrease in the peak intensities of the crystalline phases in the XRD patterns. The precipitates were amorphous when the ratio was 10 .

The surface area was the largest $\left(97 \mathrm{~m}^{2} / \mathrm{g}\right)$ when TIP was directly added to water while ultrasonic irradiation was applied [23]. It was reported by Mason and Lorimer (2002) that maximum ultrasound effect was obtained when the aqueous precipitation solution had a composition of $50 \mathrm{wt} . \%$ ethanol at $25{ }^{\circ} \mathrm{C}$ [21].

The addition of chemical species such as triblock copolymers [27], acetic acid [28] and amines [29,30] was investigated to adjust the pore/phase structure of the powders. However, an additional step, extraction by nitric acid was required to remove amines. The use of acetic acid was related with the emergence of secondary phases and the prepared powder was not crystalline at $100{ }^{\circ} \mathrm{C}$ in this investigation [28] in contrast to the observations reported in other investigations $[23,26,27,30]$. The effect of ultrasonic irradiation was not found as significant in terms of crystallite size and surface area. The surface equivalent particle size and surface area of pure anatase titania were $23 \mathrm{~nm}$ and $67 \mathrm{~m}^{2} / \mathrm{g}$ at $400{ }^{\circ} \mathrm{C}$.

This article intends to investigate the progress of nanotitania structure prepared by ultrasonic induced hydrolysis with increasing temperature in terms of phase structure and crystallite size, surface area, pore size and particle size distribution, powder density and densification behavior. The properties of these mesoporous nanocrystalline titania powders were compared with titania powder prepared without ultrasonic treatment and Degussa P-25. The dilatometric densification curves of these powders were further determined and analyzed which may generate valuable information on the microstructure evolution upon heat treatment of these promising nanomaterials.

\section{Materials and methods}

\subsection{Synthesis}

Nanocrystalline titania powders were prepared by hydrolyzing titanium isopropoxide (TIP) in ethanol-water mixture with and without the application of ultrasonic irradiation, which were labeled as $\mathrm{TiO}_{2}-\mathrm{U}$ and $\mathrm{TiO}_{2}-\mathrm{NoU}$, respectively. The schematic flowchart of the $\mathrm{TiO}_{2}-\mathrm{U}$ powder processing is shown in Fig. 1 . The TIP-ethanol mixture $(1.00 \mathrm{~mol} / \mathrm{L})$ was stirred for $30 \mathrm{~min}$ initially. Ethanol-water mixture (1:1 by volume) was subjected to ultrasonic irradiation (Ultrasonic Cleaner, $37 \mathrm{kHz}$, Elmasonic 80S), while TIP-ethanol mixture was added dropwise by using a peristaltic pump ( $10 \mathrm{~mL} / \mathrm{min})$. A typical experiment was completed in $20 \mathrm{~min}$ and the temperature of the ultrasonic bath did not exceed $40{ }^{\circ} \mathrm{C}$. The $\mathrm{TiO}_{2}-\mathrm{NoU}$ powder was prepared by following the same procedure without applying ultrasonic irradiation during hydrolysis. Bluish white precipitates were formed instantaneously and recovered by centrifugation $(8000 \mathrm{rpm}$ for $30 \mathrm{~min}$ ) at the end of precipitation. The precipitates were dried at $70{ }^{\circ} \mathrm{C}$ for $12 \mathrm{~h}$ and heat treated at different temperatures (100$800{ }^{\circ} \mathrm{C}$ ) with a heating rate of $10^{\circ} \mathrm{C} / \mathrm{min}$ and a soaking time of $2 \mathrm{~h}$

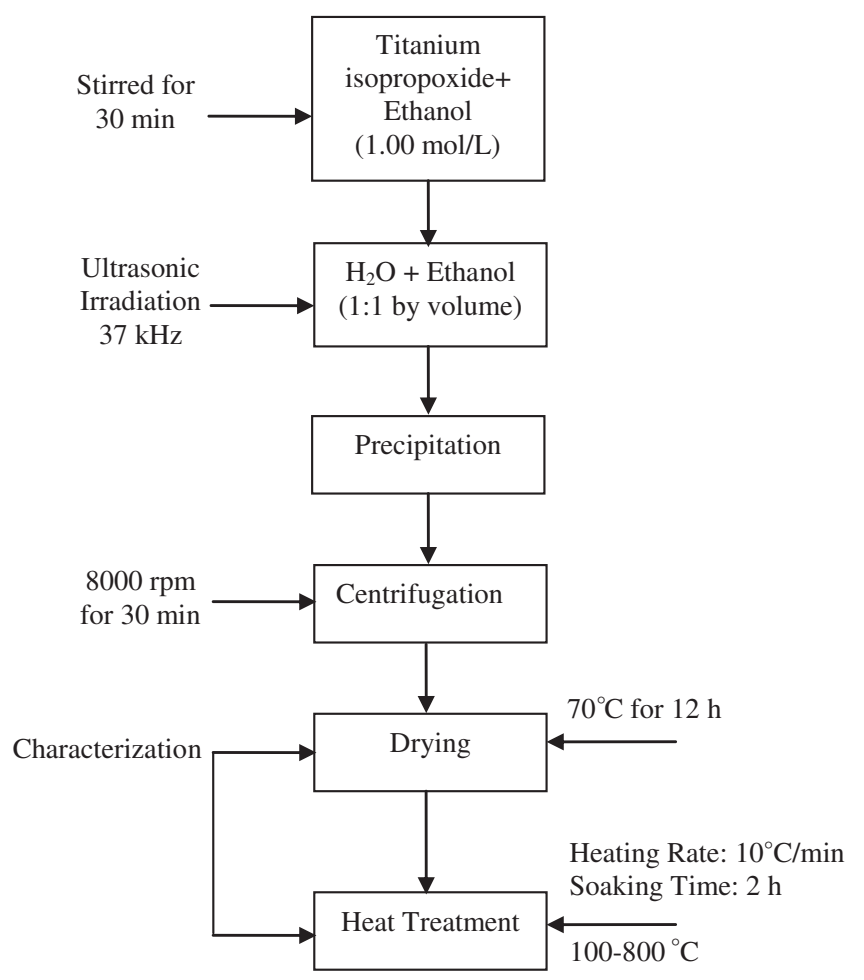

Fig. 1. Flowchart of nanocrystalline titania preparation under ultrasonic irradiation. 


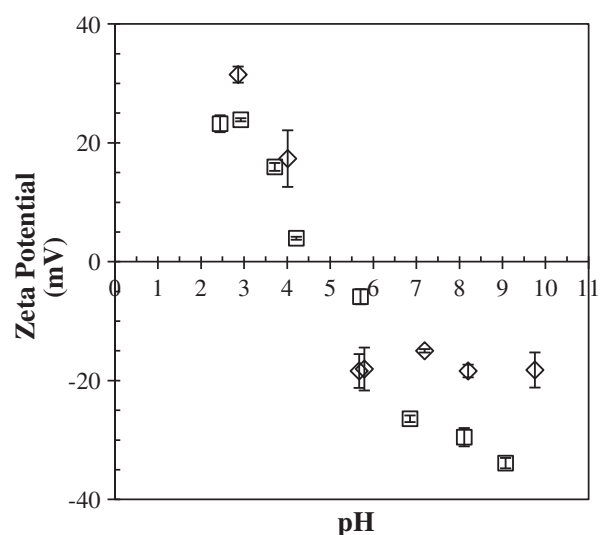

Fig. 2. The variation of zeta potentials of nanotitania $\left(\mathrm{TiO}_{2}-\mathrm{U}\right)$ heat treated at $425{ }^{\circ} \mathrm{C}$

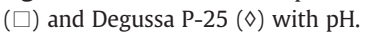

at the peak temperature. Degussa P-25, commercial titania powder was also characterized similarly.

\subsection{Characterization methods}

The particle size distributions and isoelectric (IEP) points of the powders were determined by using ZetaSizer ( $3000 \mathrm{HS}_{\mathrm{A}}$, Malvern). Dilute suspensions were prepared by adding about $0.5 \mathrm{mg}$ of powder into a UV cuvette in about $2-3 \mathrm{~mL}$ of ultrapure water. The dispersion was subjected to ultrasonic treatment for $30 \mathrm{~min}$ before measurement. The $\mathrm{pH}$ was adjusted by adding dilute nitric acid and ammonia solution for the zeta potential measurements. The IEP measurements were repeated three times and the standard deviations were indicated in the related figure. The BET surface area of the powders and the $\mathrm{BJH}$ desorption curves were determined by $\mathrm{N}_{2}$ sorption by using Micromeritics ASAP 2000. The samples were degassed at a temperature which was $50{ }^{\circ} \mathrm{C}$ below powder heat treatment temperature. An adsorption data in the relative pressure $\left(\mathrm{P} / \mathrm{P}_{\mathrm{o}}\right)$ range of $0.05-0.3$ was used to determine the surface area by BET (Brunauer-EmmettTeller) method. Desorption data was used to determine the pore size distribution by BJH (Barret-Joyner-Halender) method by assuming a cylindrical pore model. These sorption characterizations were carried out only once on each sample since they were approximately one day long runs. He pycnometer was used to determine the density of the powders at room temperature. The density measurements were repeated three times and the average density was calculated. The XRD patterns were obtained by Philips Expert Pro XRD using $\mathrm{CuK}_{\alpha}$ radiation in the $20-60^{\circ} 2 \theta$ range and only one pattern for each sample was obtained. The average crystallite size (ACS) of the powders was calculated by using Scherrer equation from the fullwidth half-maximum of the peak of each phase after correcting for the instrumental broadening by using the X'PERT PLUS program (version 1.0, 23.04.1999). Due to the overlap of anatase (110) peak with brookite (120) and (111) peaks, the ACS of the samples was calculated from the second strongest anatase peak (200) located at $2 \theta$ of $\sim 48^{\circ}$. The ACS of rutile was calculated from the (110) peak which is located at $2 \theta$ of $\sim 27^{\circ}$. Anatase, brookite, and rutile phase contents of the powders were determined by using the following equations:

$w_{\mathrm{A}} \%=\frac{100 \cdot k_{A} I_{A}}{k_{A} I_{A}+I_{R}+k_{B} I_{B}}$

$w_{\mathrm{R}} \%=\frac{100 \cdot I_{R}}{k_{A} I_{A}+I_{R}+k_{B} I_{B}}$

$w_{\mathrm{B}} \%=\frac{100 \cdot k_{B} I_{B}}{k_{A} I_{A}+I_{R}+k_{B} I_{B}}$

where $w_{\mathrm{A}}, w_{\mathrm{B}}$, and $w_{\mathrm{R}}$ are weight percents of anatase, brookite, and rutile phases in the sample, $I_{A}, I_{B}$, and $I_{R}$ are integrated peak intensities of the strongest anatase (101), brookite (211), and rutile (110) peaks. The coefficients $k_{A}$ and $k_{B}$ are obtained from previous work as 0.886 and $2.721[26,27,31]$.

The TGA curves of the powders were obtained by heating to a maximum temperature of $1000{ }^{\circ} \mathrm{C}$ under $\mathrm{N}_{2}$ atmosphere at a heating rate of $10^{\circ} \mathrm{C} / \mathrm{min}$. The densification behavior of the powder compacts isostatically pressed at $210 \mathrm{MPa}$ was determined by using a dilatometer (Linseis, L76/150B) with a heating rate of 5 or $10^{\circ} \mathrm{C} / \mathrm{min}$ up to $1200^{\circ} \mathrm{C}$. TGA and dilatometric measurements were conducted only once on each sample reported in this work.

\section{Results and discussion}

The variation of the zeta potentials of the powders with $\mathrm{pH}$ is shown in Fig. 2. The IEP of the nanotitania powder $\left(\mathrm{TiO}_{2}-\mathrm{U}\right)$ and Degussa P-25 powder was about 5 . Due to the relatively low zeta potential values which are 5.1 and $-16.1 \mathrm{mV}$ at $\mathrm{pH}$ values of 4 and 6 , the $\mathrm{TiO}_{2}$-U powder was considered colloidally unstable in this
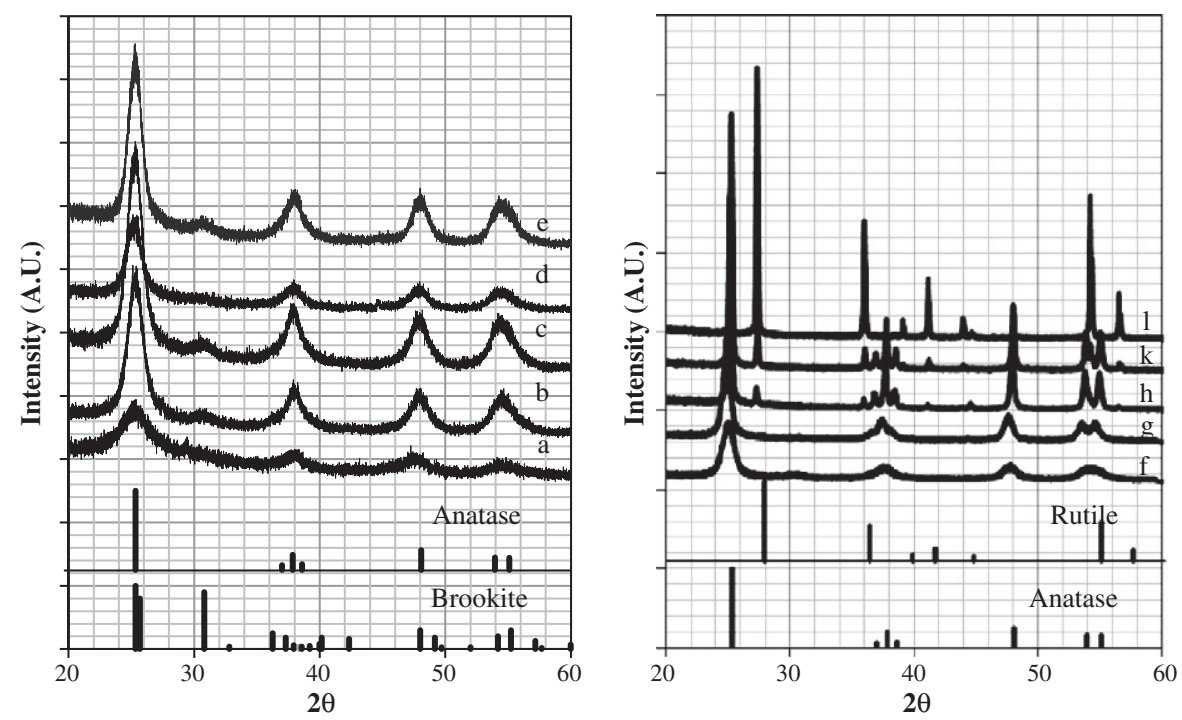

Fig. 3. The XRD patterns of $\mathrm{TiO}_{2}-\mathrm{NoU}$ heat treated at (a) 25, (b) 70, (c) 100, (d) 250, (e) 300, (f) 400, (g) 500, (h) 600, (k) 700 and (l) $800{ }^{\circ} \mathrm{C}$. 

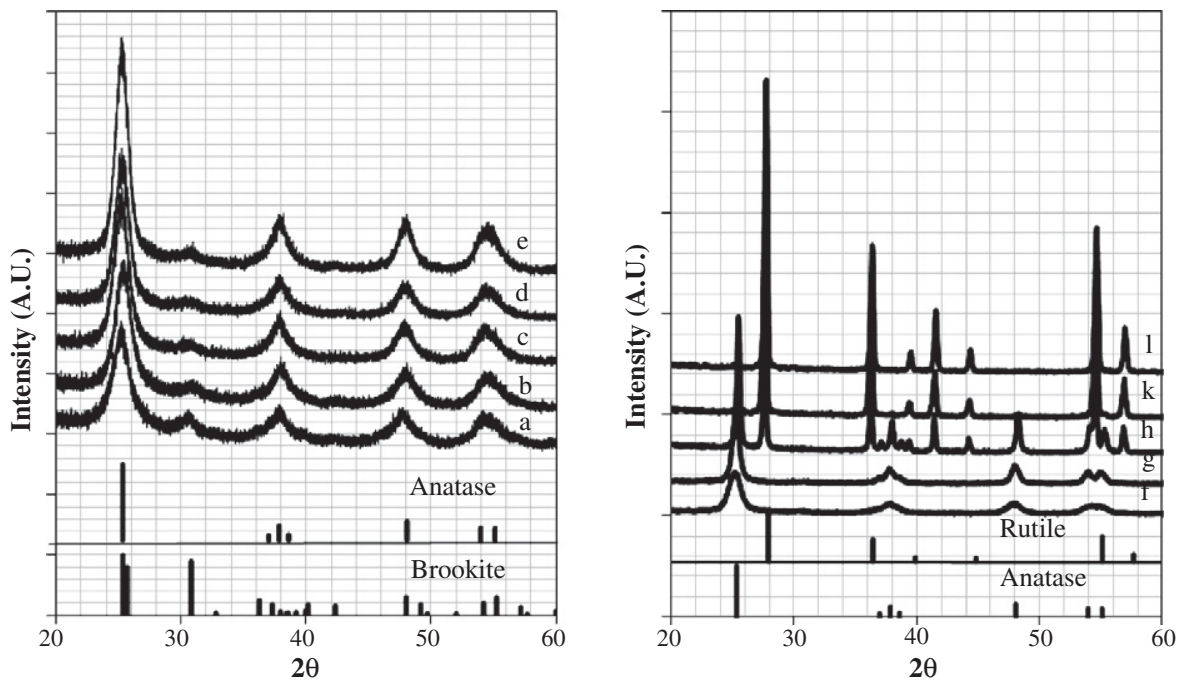

Fig. 4. The XRD patterns of $\mathrm{TiO}_{2}$-U heat treated at (a) 25, (b) 70, (c) 150, (d) 250, (e) 300, (f) 400, (g) 500, (h) 600, (k) 700 and (l) $800{ }^{\circ} \mathrm{C}$.

range. Higher zeta potentials as 23 and $-30 \mathrm{mV}$ at $\mathrm{pH}$ levels of 2.9 and 8.1 were determined.

The effects of ultrasonic irradiation and heat treatment temperature on the ACS and phase contents of the powders were determined from their XRD patterns based on the standard XRD patterns of anatase, brookite, and rutile phases (JCPDS 84-1286, 29-1360, and $88-1175$, respectively). Although only broad anatase peaks were detected in the XRD pattern of $\mathrm{TiO}_{2}-\mathrm{NoU}-25$, the brookite peak $\left(\sim 30.8^{\circ}\right.$ of $\left.2 \theta\right)$ became detectable in the $70-400{ }^{\circ} \mathrm{C}$ range (Fig. 3 ). The rutile phase formation started at above $500{ }^{\circ} \mathrm{C}$ and was completed at $\sim 800^{\circ} \mathrm{C}$. The brookite and anatase peaks became sharper in the ultrasonically treated powders compared to their counter parts in the untreated powders as can be seen in Figs. 3 and 4. The brookite phase completely transformed into anatase in the $400-500{ }^{\circ} \mathrm{C}$ temperature range. The anatase to rutile phase transformation started at lower than $600{ }^{\circ} \mathrm{C}$ and was completed at temperatures in between 700 and $800{ }^{\circ} \mathrm{C}$ range for $\mathrm{TiO}_{2}-\mathrm{U}$.

The weight percentages of the crystalline phases were determined as outlined previously and further plotted as a function of temperature in Fig. 5. The $\mathrm{TiO}_{2}-\mathrm{NoU}$ powder consists of only anatase phase ( $100 \mathrm{wt} . \%)$ in the room temperature to $70^{\circ} \mathrm{C}$ range. The brookite phase (10-13 wt.\%) which forms at $\sim 70{ }^{\circ} \mathrm{C}$, completely transformed to anatase in the $400-500{ }^{\circ} \mathrm{C}$ range. It was observed that the application of ultrasonic irradiation favors the formation of the brookite phase ( $60 \mathrm{wt} . \%$ of anatase and $40 \mathrm{wt} . \%$ of brookite for $\mathrm{TiO}_{2}-\mathrm{U}-25$ ).
However, the amount of the brookite phase decreased to $25 \mathrm{wt} . \%$ at $70{ }^{\circ} \mathrm{C}$. The $\mathrm{TiO}_{2}-\mathrm{U}$ powder contained $9 \mathrm{wt} . \%$ brookite phase at $400{ }^{\circ} \mathrm{C}$ and pure anatase was obtained by heating to $500{ }^{\circ} \mathrm{C}$. The anatase to rutile phase transformation occurred above $500{ }^{\circ} \mathrm{C}$ and was completed at $800{ }^{\circ} \mathrm{C}$ for both powders.

Particle coarsening in the powders during phase transformation was detected via analyzing the increase in the ACS of the anatase phase determined by using Scherrer equation and surface area equivalent particle size (SAEPS) (Fig. 6). The ACS of $\mathrm{TiO}_{2}-\mathrm{NoU}-25$ which was two times larger than the $\mathrm{TiO}_{2}-\mathrm{U}-25$, did not change significantly $(\sim 10 \mathrm{~nm})$ in the $70-400{ }^{\circ} \mathrm{C}$ range. It increased significantly in the $500-800{ }^{\circ} \mathrm{C}$ temperature range where also anatase-rutile transformation occurred. The increases in $\mathrm{ACS}$ for $\mathrm{TiO}_{2}-\mathrm{U}$ powder were observed to occur at two separate temperature ranges of 25-200 and 400$600{ }^{\circ} \mathrm{C}$. The ACS of $\mathrm{TiO}_{2}$ - $\mathrm{U}$ powder was almost constant during phase transformations at temperatures of $250-400{ }^{\circ} \mathrm{C}$ (brookite to anatase) and $600-700{ }^{\circ} \mathrm{C}$ (anatase to rutile). A significant increase in crystallite size was observed in the $400-800{ }^{\circ} \mathrm{C}$ range for both powders. The SAEPS was calculated from BET surface areas by assuming that the particles are non-porous spherical particles and was quite comparable with the XRD data driven ACS in the $200-500{ }^{\circ} \mathrm{C}$ range as seen in Fig. 5. The crystallite size of Degussa P-25 powder was calculated as $17 \mathrm{~nm}$ based on the strongest (110) anatase peak).

The $\mathrm{N}_{2}$ adsorption-desorption isotherms of both $\mathrm{TiO}_{2}-\mathrm{U}$ and $\mathrm{TiO}_{2^{-}}$ NoU powders heat treated at different temperatures $\left(200-500{ }^{\circ} \mathrm{C}\right)$ (a)

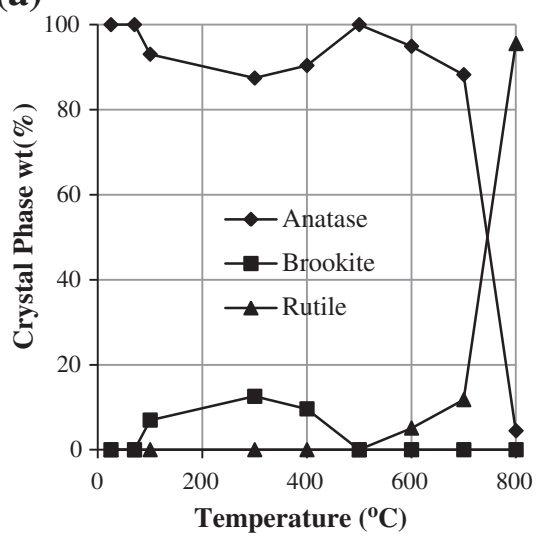

(b)

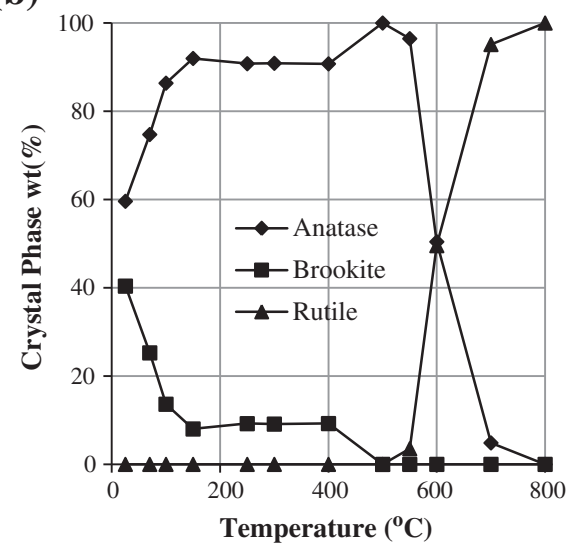

Fig. 5. The variation of the wt.\% of the crystalline phases present in (a) TiO2-NoU and (b) TiO2-U powders with respect to temperature. 
(a)

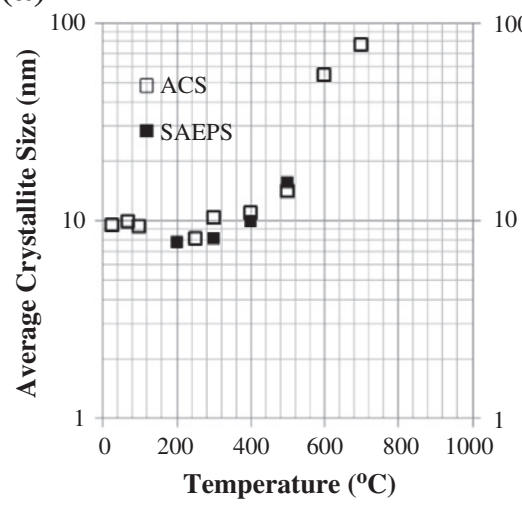

(b)

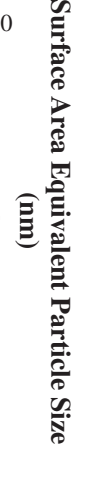

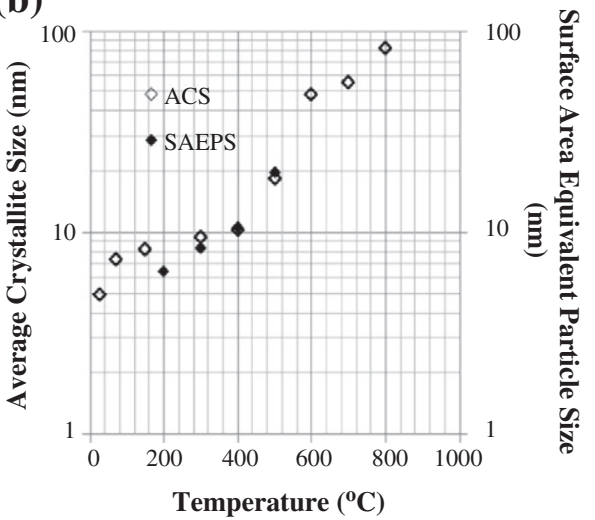

Fig. 6. The effect of temperature on average crystallite size (ACS) and surface equivalent particle size (SAEPS) of (a) $\mathrm{TiO}_{2}-\mathrm{NoU}_{\text {and }}$ of $(\mathrm{b}) \mathrm{TiO} \mathrm{O}_{2}-\mathrm{U}$ powders.

exhibit type IV isotherms with H3 hysteresis loops [32,33]. The locations and the forms of the hysteresis loops indicated high adsorption energy and mesoporous structure with slit shaped pores in the range of 2-50 nm (Figs. 7 and 8) according to BDDT (Brunauer, Deming, Deming and Teller) classification. However, the Degussa P-25 powder had type II adsorption isotherm which is characteristic of non-porous or macroporous structures with high adsorption energy (Fig. 9).
The hysteresis loop of $\mathrm{TiO}_{2}$-NoU-200 was located in the relative pressure range of $0.5-1$ and gradually shifted to $0.6-1$ relative pressure range when it was heat treated at $400{ }^{\circ} \mathrm{C}$. The pore volumes of $\mathrm{TiO}_{2}$-NoU powders $\left(\sim 0.36 \mathrm{~m}^{3} / \mathrm{g}\right)$ did not change significantly, but broader pore size distributions and a monotonic decrease in the BET surface areas were determined by increasing the heat treatment temperature up to $400{ }^{\circ} \mathrm{C}$ (Table 1 and Fig. 10a). The average pore size (a)

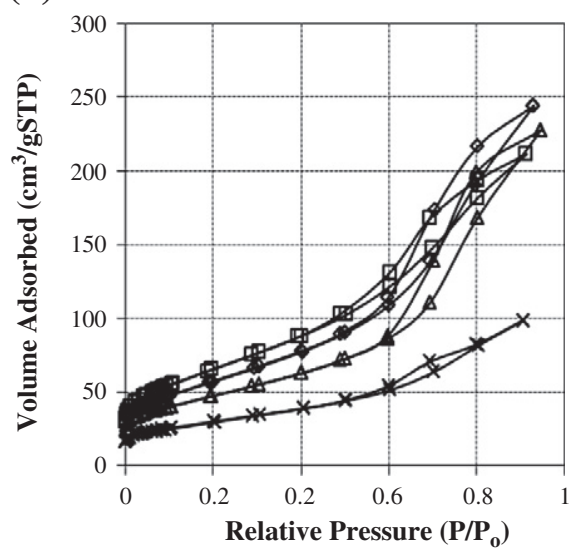

(b)

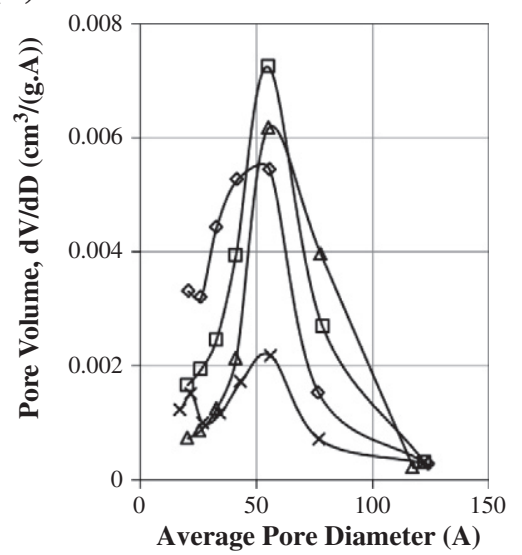

Fig. 7. (a) The $\mathrm{N}_{2}$-sorption isotherms and (b) BJH desorption pore size distributions of $\mathrm{TiO}_{2}$-NoU titania powders heated at $200(\square)$, $300(\diamond), 400(\Delta)$, and $500{ }^{\circ} \mathrm{C}(\times)$.

(a)

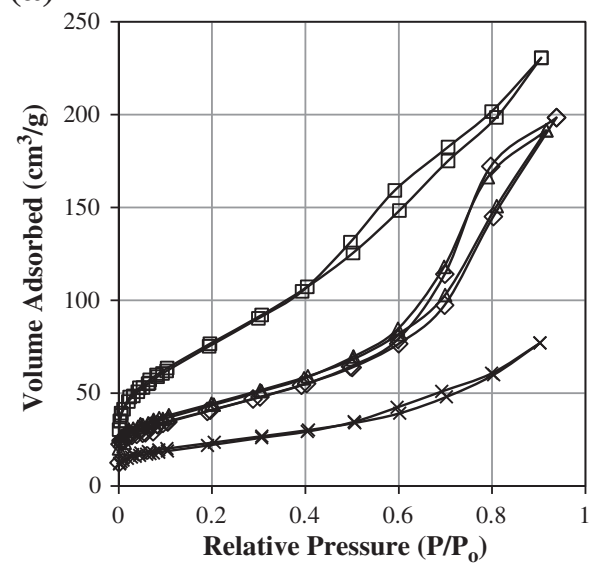

(b)

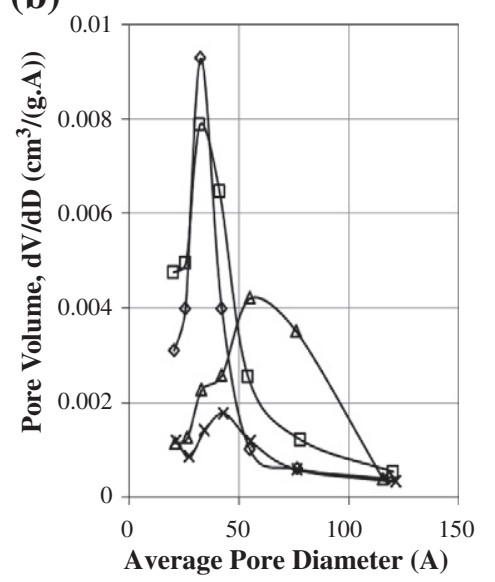

Fig. 8. (a) The $\mathrm{N}_{2}$-sorption isotherms and (b) BJH desorption pore size distributions of $\mathrm{TiO}_{2}$-U titania powders heated at $200(\square), 300(\diamond), 400(\Delta)$,and $500{ }^{\circ} \mathrm{C}(\times)$. 
(a)

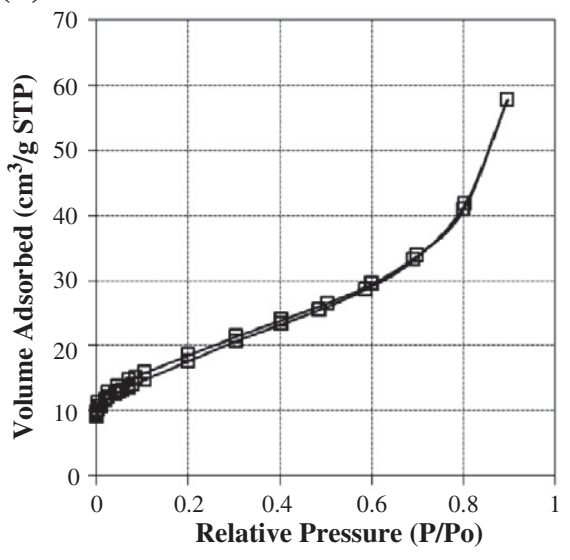

(b)

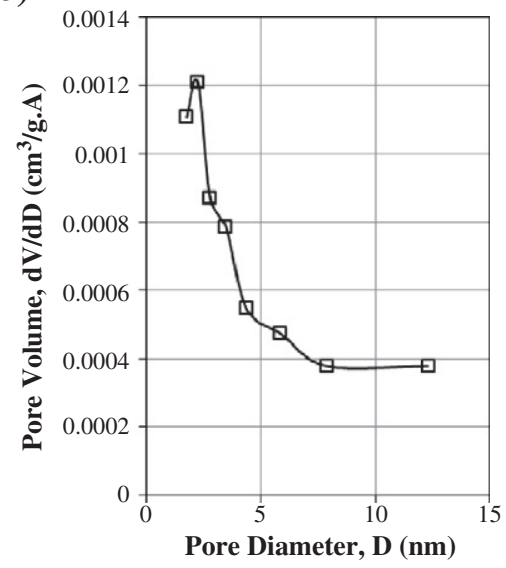

Fig. 9. (a) The $\mathrm{N}_{2}$-sorption isotherms and (b) BJH desorption pore size distribution of Degussa P-25 ( $\square$ ).

Table 1

The pore/phase structure properties, surface areas and He pycnometer densities of the powders.

\begin{tabular}{|c|c|c|c|c|c|c|c|c|}
\hline Sample & $\begin{array}{l}\text { Average crystallite size } \\
(\mathrm{nm})\end{array}$ & $\begin{array}{l}\text { Anatase content } \\
\left(\% w_{\mathrm{A}}\right)\end{array}$ & $\begin{array}{l}\text { Brookite content } \\
\left(\% w_{\mathrm{B}}\right)\end{array}$ & $\begin{array}{l}\text { Rutile content } \\
\left(\% w_{\mathrm{R}}\right)\end{array}$ & $\begin{array}{l}\text { Density } \\
\left(\mathrm{g} / \mathrm{cm}^{3}\right)\end{array}$ & $\begin{array}{l}\text { BET } \\
\left(\mathrm{m}^{2} / \mathrm{g}\right)\end{array}$ & $\begin{array}{l}\text { Average pore size }{ }^{a} \\
(\mathrm{~nm})\end{array}$ & $\begin{array}{l}\text { Pore volume } \\
\left(\mathrm{cm}^{3} / \mathrm{g}\right)\end{array}$ \\
\hline $\mathrm{TiO}_{2}-\mathrm{NoU}-25$ & 9.9 & 100 & - & - & - & - & - & - \\
\hline $\mathrm{TiO}_{2}-\mathrm{NoU}-70$ & 9.7 & 100 & - & - & - & - & - & - \\
\hline $\mathrm{TiO}_{2}-\mathrm{NoU}-100$ & 9.3 & 97 & 3 & - & - & - & - & - \\
\hline $\mathrm{TiO}_{2}-\mathrm{NoU}-200$ & - & - & - & - & - & 238 & 5.5 & 0.327 \\
\hline $\mathrm{TiO}_{2}-\mathrm{NoU}-300$ & 10.2 & 87 & 13 & - & - & 209 & 7.2 & 0.378 \\
\hline $\mathrm{TiO}_{2}-\mathrm{NoU}-400$ & 10.9 & 90 & 10 & - & - & 170 & 8.2 & 0.352 \\
\hline $\mathrm{TiO}_{2}-\mathrm{NoU}-500$ & 14 & 100 & - & - & - & 106 & 5.7 & 0.153 \\
\hline $\mathrm{TiO}_{2}-\mathrm{NoU}-600$ & 54 & 95 & - & 5 & - & - & - & - \\
\hline $\mathrm{TiO}_{2}$-NoU-700 & 78 & 88 & - & 12 & - & - & - & - \\
\hline $\mathrm{TiO}_{2}-\mathrm{NoU}-800$ & $292^{\mathrm{b}}$ & 4 & - & 96 & - & - & - & - \\
\hline $\mathrm{TiO}_{2}-\mathrm{U}-25$ & 4.9 & 60 & 40 & - & - & - & - & - \\
\hline $\mathrm{TiO}_{2}-\mathrm{U}-70$ & 7.3 & 75 & 25 & - & 3.19 & - & - & - \\
\hline $\mathrm{TiO}_{2}-\mathrm{U}-150$ & 8.2 & 92 & 8 & - & - & - & - & - \\
\hline $\mathrm{TiO}_{2}-\mathrm{U}-100$ & 8 & 86 & 14 & - & - & - & - & - \\
\hline $\mathrm{TiO}_{2}-\mathrm{U}-200$ & - & - & - & - & 3.27 & 287 & 4.2 & 0.336 \\
\hline $\mathrm{TiO}_{2}-\mathrm{U}-250$ & 8.1 & 91 & 9 & - & - & - & - & - \\
\hline $\mathrm{TiO}_{2}-\mathrm{U}-300$ & 9.4 & 91 & 9 & - & 3.57 & 201 & 4 & 0.246 \\
\hline $\mathrm{TiO}_{2}-\mathrm{U}-400$ & 10.3 & 91 & 9 & - & 3.57 & 159 & 5.9 & 0.297 \\
\hline $\mathrm{TiO}_{2}-\mathrm{U}-500$ & 18.4 & 100 & - & 0 & 3.68 & 82 & 5.4 & 0.117 \\
\hline $\mathrm{TiO}_{2}-\mathrm{U}-600$ & 48 & 50 & & 50 & 4.06 & - & - & - \\
\hline $\mathrm{TiO}_{2}-\mathrm{U}-700$ & $55^{\mathrm{b}}$ & 5 & - & 95 & 4.00 & - & - & - \\
\hline $\mathrm{TiO}_{2}-\mathrm{U}-800$ & $81^{\mathrm{b}}$ & - & - & 100 & 4.13 & - & - & - \\
\hline Degussa P-25 & 17 & 13 & - & 97 & - & 66 & 5 & 0.09 \\
\hline
\end{tabular}

a From BJH desorption data.

b Calculated from X-ray peak of rutile located at $27.2^{\circ}$ of $2 \theta$.

(a)

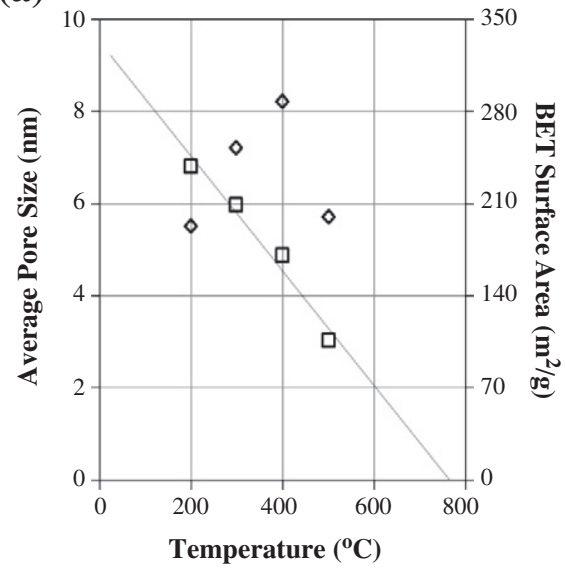

(b)

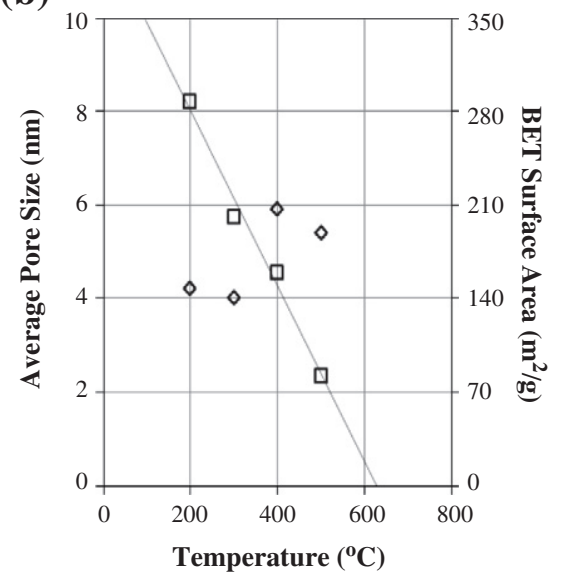

Fig. 10. The variation of BET surface area $(\square)$ and pore size based on BJH desorption $(\diamond)$ with temperature of (a) $\mathrm{TiO}_{2}-\mathrm{NoU}$ and $(\mathrm{b}) \mathrm{TiO}_{2}$-U powders. 


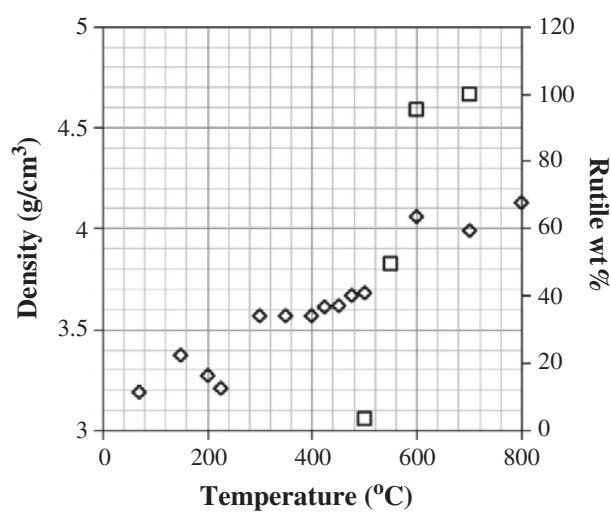

Fig. 11. The variation of density of nanotitania $(\diamond)$ and $w_{R}$, \% rutile, ( $\square$ ) with respect to temperature for $\mathrm{TiO}_{2}-\mathrm{U}$.

became larger ( 5.5 to $8.2 \mathrm{~nm}$ ) in the $200-400{ }^{\circ} \mathrm{C}$ range due to the formation of larger aggregates while the $\mathrm{BJH}$ pore volume did not change significantly $\left(0.327\right.$ to $0.357 \mathrm{~cm}^{3} / \mathrm{g}$ ) for $\mathrm{TiO}_{2}$-NoU powder. The average pore size, pore volume and surface area decreased to $5.7 \mathrm{~nm}, 0.153 \mathrm{~cm}^{3} / \mathrm{g}$ and $106 \mathrm{~m}^{2} / \mathrm{g}$, respectively, at $500{ }^{\circ} \mathrm{C}$ due to the formation of densely packed aggregates.

(a)

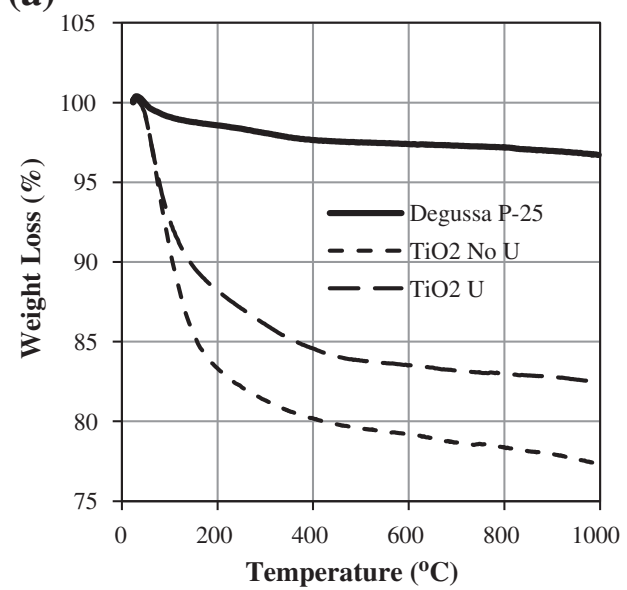

The variation of the hysteresis loop form and location for $\mathrm{TiO}_{2}-\mathrm{U}$ powder with temperature have shown a two-step progress: the shift to a higher relative pressure range $\left(\mathrm{P} / \mathrm{P}_{\mathrm{o}} \sim 0.4-1\right.$ to $\left.0.5-1\right)$ by increasing calcination temperature from 200 to $300 / 400{ }^{\circ} \mathrm{C}$ and a further narrowing of the relative pressure range $\left(\mathrm{P} / \mathrm{P}_{\mathrm{o}} \sim 0.5-1\right.$ to $0.5-$ 0.8 ) at $500{ }^{\circ} \mathrm{C}$ (Fig. 8). Similarly, the pore size distribution became narrower by heating up to $300{ }^{\circ} \mathrm{C}$ and became wider by further heat treatment. The BET surface area (from 287 to $80 \mathrm{~m}^{2} / \mathrm{g}$ ) and the BJH pore volume (from 0.334 to $0.117 \mathrm{~cm}^{3} / \mathrm{g}$ ) decreased significantly by increasing the heat treatment temperature from 200 to $500{ }^{\circ} \mathrm{C}$ whereas the average pore size didn't change significantly $(\sim 4-5.4 \mathrm{~nm})$ for $\mathrm{TiO}_{2}$-U powder (Table 1 and Fig. 10b). The first step may be dominated by the formation of anatase phase and crystal growth which eliminated inter-particle pores in the $200-400{ }^{\circ} \mathrm{C}$ range. The second step may be related to the reduction of smaller pores preferentially and the presence of larger pores due to the formation of closely packed aggregates while heating from 400 to $500{ }^{\circ} \mathrm{C}[34,35]$.

The pore/phase structure properties, surface areas and He pycnometer densities of the powders are further tabulated in Table 1. The variation of the powder densities with heat treatment temperature is given in Fig. 11. The densities of the powders were determined to be above $4.00 \mathrm{~g} / \mathrm{cm}^{3}$ for heat treatment temperatures above $600{ }^{\circ} \mathrm{C}$ which became comparable with the density of rutile in agreement with the XRD results. The powder density is almost constant in the $300-500{ }^{\circ} \mathrm{C}$ range (in the $3.57-3.68 \mathrm{~g} / \mathrm{cm}^{3}$ ) which is close to the

(b)

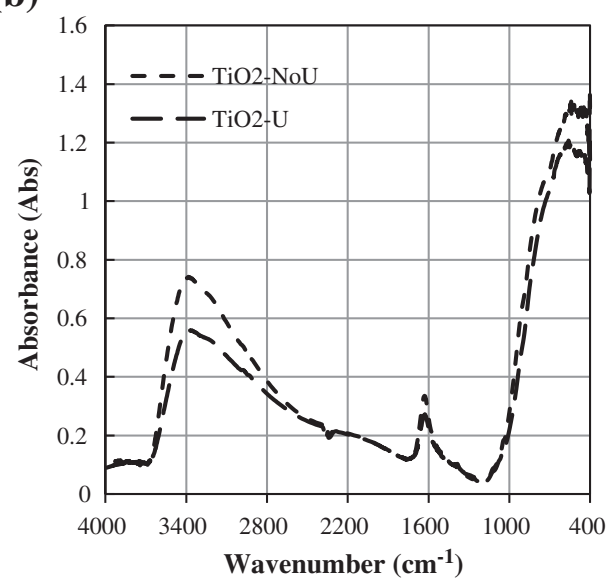

Fig. 12. (a) TGA curves of Degussa $\mathrm{P}-25, \mathrm{TiO}_{2}-\mathrm{NoU}$ and $\mathrm{TiO}_{2}-\mathrm{U}$ under $\mathrm{N} 2$ atmosphere (b) FTIR curves of $\mathrm{TiO}_{2}-\mathrm{NoU}$ and $\mathrm{TiO}{ }_{2}-\mathrm{U}$ powders which were dried at $25{ }^{\circ} \mathrm{C}$.

(a)

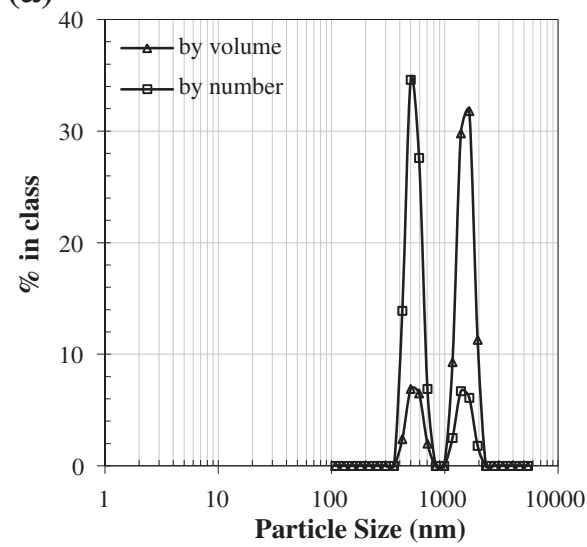

(b)

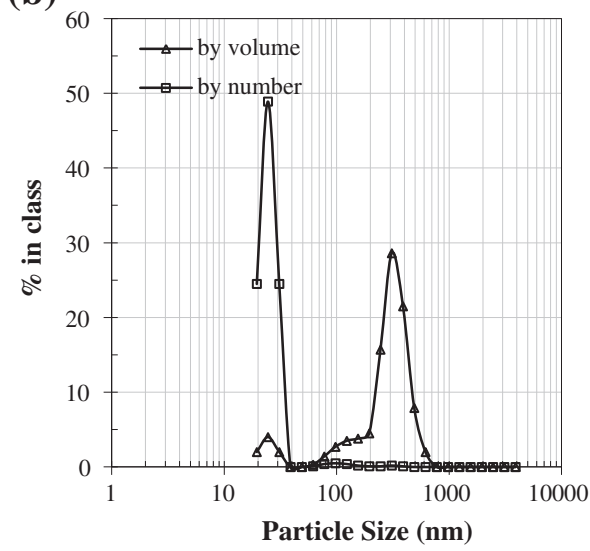

(c)

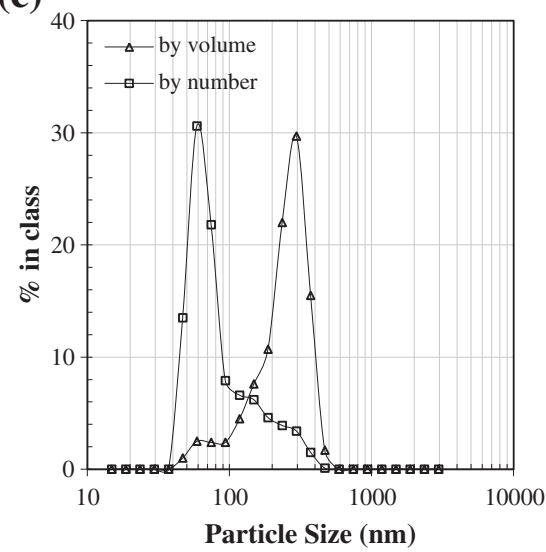

Fig. 13. The particle size distribution of (a) $\mathrm{TiO}_{2}-\mathrm{U}$ as precipitated, (b) $\mathrm{TiO}_{2}-\mathrm{U}-425$, and (c) Degussa $\mathrm{P}-25$ by DLS measurement. 
Table 2

The average particle size of $\mathrm{TiO}_{2}-\mathrm{U}$ and Degussa P-25 by volume and by number.

\begin{tabular}{lccll}
\hline Sample & $\begin{array}{c}\text { Particle size by } \\
\text { volume }(\mathrm{nm})\end{array}$ & $\begin{array}{l}\text { Particle size by } \\
\text { number }(\mathrm{nm})\end{array}$ & $\begin{array}{l}\text { Polydispersity } \\
\text { index }\end{array}$ & $\begin{array}{l}\text { SAEPS } \\
(\mathrm{nm})\end{array}$ \\
\hline $\mathrm{TiO}_{2}$-U as precipitated & $545(18 \%)$ & $549(83 \%)$ & 0.062 & - \\
& $1536(82 \%)$ & $1545(17 \%)$ & & \\
$\mathrm{TiO}_{2}-\mathrm{U}-425$ & $25(8 \%)$ & $25(98 \%)$ & 0.475 & 9.7 \\
& $309(92 \%)$ & $109(2 \%)$ & & 22 \\
Degussa P-25 & $72(8 \%)$ & $98(100 \%)$ & - & \\
& $259(92 \%)$ & & & \\
\hline
\end{tabular}

anatase phase density. The density increases with heat treatment temperature initially with a subsequent decrease in the $70-225^{\circ} \mathrm{C}$ range which may be attributed to the brookite phase transformation to anatase and the rearrangements in the amorphous phase present in the powders. The powder density was $4.13 \mathrm{~g} / \mathrm{cm}^{3}$ at $800{ }^{\circ} \mathrm{C}$ after the completion of anatase to rutile phase transformation (in the $500-800{ }^{\circ} \mathrm{C}$ range).

The TGA curve of the titania powders (dried at room temperature) and Degussa P-25 are given in Fig. 12a. Degussa P-25 powder lost about $3 \mathrm{wt} . \%$ of its original weight in the $25-1000{ }^{\circ} \mathrm{C}$ range, which was attributed to the removal of physically adsorbed water from powder surface. Total weight loss of $\mathrm{TiO}_{2}-\mathrm{NoU}$ and $\mathrm{TiO}_{2}-\mathrm{U}$ powders up to $1000{ }^{\circ} \mathrm{C}$ was 23 and $17.5 \mathrm{wt} . \%$, respectively. The weight loss in the $25-80{ }^{\circ} \mathrm{C}$ range was about $5 \mathrm{wt} . \%$ for both titania powders which was attributed to the removal of physically/chemically adsorbed water and ethanol. The weight loss of $\mathrm{TiO}_{2}-\mathrm{NoU}$ was about 5 wt.\% higher than $\mathrm{TiO}_{2}-\mathrm{U}$ powder with further heating to $200{ }^{\circ} \mathrm{C}$ and this behavior may be related to the presence of $\mathrm{Ti}(\mathrm{OH})_{4}$ and its transformation to $\mathrm{TiO}_{2}$ upon further heating which was confirmed by FTIR spectrum (Fig. 12b). The broad peak located at $3340 \mathrm{~cm}^{-1}$ indicated the presence of surface hydroxyls $\left(\mathrm{Ti}(\mathrm{OH})_{4}\right)$. The adsorbed water was detected by the peak located at $1620 \mathrm{~cm}^{-1}$. The intensities of the defined peaks for $\mathrm{TiO}_{2}-\mathrm{NoU}$ were higher than $\mathrm{TiO}_{2}-\mathrm{U}$ which was consistent with the presence of a higher level of $\mathrm{Ti}(\mathrm{OH})_{4}$ in $\mathrm{TiO}_{2}$-NoU.

The particle size distributions and the average particle sizes of $\mathrm{TiO}_{2}$-U and Degussa P-25 powders are given in Fig. 13 and Table 2. The particle size of Degussa P-25 by dynamic light scattering (DLS) was almost five times higher than the SAEPS. Although DLS operates on the assumption of the presence of homogenous and nonabsorbing spherical particles in dilute suspensions, this assumption may be violated due to non-spherical shape and porous powders. The as-precipitated particles $\left(\mathrm{TiO}_{2}-\mathrm{U}\right)$ were partially crystalline and contained hydroxyl groups, chemically adsorbed water and ethanol based on the findings of XRD, TGA and FTIR analyses. They may have larger surface area than $\mathrm{TiO}_{2}-\mathrm{U}-200\left(287 \mathrm{~m}^{2} / \mathrm{g}\right)$ and were largely agglomerated. The most of $\mathrm{TiO}_{2}-\mathrm{U}$ as precipitated particles was about $550 \mathrm{~nm}$ ( $83 \%$ of particles) in size by number. The particle size of $\mathrm{TiO}_{2}$-U-425 $\left(146 \mathrm{~m}^{2} / \mathrm{g}\right)$ was about $25 \mathrm{~nm}$ (97.8 and $2.2 \%$ of nanoparticles were 25 and $109 \mathrm{~nm}$ in size by number, respectively) due to the removal of adsorbed chemicals and progress of crystalline phases during heat treatment.

The polydispersity index (PDI) values of the measurements are given in Table 2. The PDI value is related with the dispersivity and varies between 0 and 1 . The more monodisperse the particles are, the lower the PDI value. $\mathrm{TiO}_{2}-\mathrm{U}$ as precipitated powder contained $500 \mathrm{~nm}$ and $1.5 \mu \mathrm{m}$ particles in size which correspond to amorphous aggregates formed in the precipitation medium and their larger agglomerates. The PDI value of particle size measurement for $\mathrm{TiO}_{2}-\mathrm{U}-$ 425 powder was 0.475 which represents a broader particle size distribution. This may be due to the formation of a relatively large amount of smaller particles ( $25 \mathrm{~nm}$ in size which is closer to the $10 \mathrm{~nm}$ crystallite size) during the removal of hydroxyl groups and the formation of crystalline phases and aggregates upon heat treatment.

The powder compacts had a densification behavior which was formed of two stages, which are given in Fig. 14a and b. There was no significant shrinkage ( $2 \%$ ) present in $\mathrm{TiO}_{2}$-NoU and $\mathrm{TiO}_{2}-\mathrm{U}$ powder compacts up to $200{ }^{\circ} \mathrm{C}$ and $400{ }^{\circ} \mathrm{C}$ for Degussa P-25 powder compacts regardless of heating rate. The first stage in the $500-850{ }^{\circ} \mathrm{C}$ range may most likely be controlled by the $7-10 \mathrm{~nm}$ crystallites in the structure and account for $18 \%$ of the total $26 \%$ shrinkage at $1200{ }^{\circ} \mathrm{C}$ with a heating rate of $10^{\circ} \mathrm{C} / \mathrm{min}$. The second stage starting from $850{ }^{\circ} \mathrm{C}$ may be due to the sintering of densified submicron original aggregates of the powder primary crystallites. The densification of $\mathrm{TiO}_{2}-\mathrm{NoU}$ and $\mathrm{TiO}_{2}-\mathrm{U}$ powders still was not completed by $1200{ }^{\circ} \mathrm{C}$.

The progress of microstructure development, sintering stages, and phase transformations of the powder compacts with respect to temperature can be differentiated by evaluation of the first derivatives of the shrinkage curves (Fig. 15a and b). The peak temperatures were $\sim 30{ }^{\circ} \mathrm{C}$ higher upon increasing the heating rate from 5 to $10{ }^{\circ} \mathrm{C} / \mathrm{min}$. There was no shrinkage at temperatures up to $400{ }^{\circ} \mathrm{C}$ for powder compacts of Degussa P-25compacts. Increasing the heating rate from 5 to $10{ }^{\circ} \mathrm{C} / \mathrm{min}$ lowers the peak temperatures of sintering stages for anatase (C) and rutile (E) as seen Fig. 15a and b. The $\mathrm{TiO}_{2}$-NoU powder compacts had a slightly higher total shrinkage at $1200{ }^{\circ} \mathrm{C}$ although the peak densification temperatures were the same. The removal of hydroxides was observed at $200{ }^{\circ} \mathrm{C}$ for $\mathrm{TiO}_{2}-$ $\mathrm{NoU}$ and $\mathrm{TiO}_{2}-\mathrm{U}$ while brookite to anatase phase transformation was in progress (A). The phase transformation of brookite to anatase was not detected from the first derivatives of the shrinkage curves in the $300-500{ }^{\circ} \mathrm{C}$ range (B) due to the low content of brookite (13 and (a)

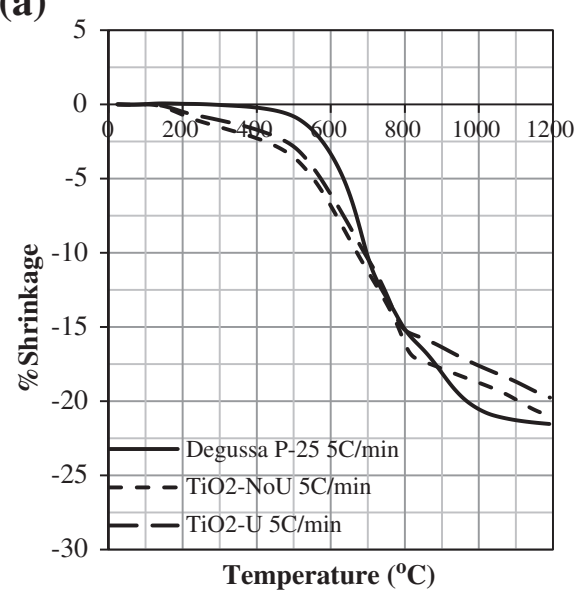

(b)

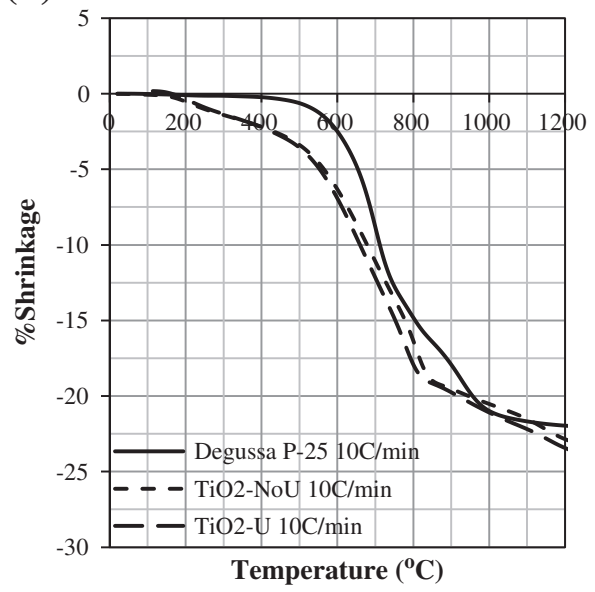

Fig. 14. The shrinkage curves of Degussa $\mathrm{P}-25, \mathrm{TiO}_{2}-\mathrm{NoU}$ and $\mathrm{TiO}_{2}-\mathrm{U}$ at a heating rate of (a) $5{ }^{\circ} \mathrm{C} / \mathrm{min}$ and (b) $10^{\circ} \mathrm{C} / \mathrm{min}$. 

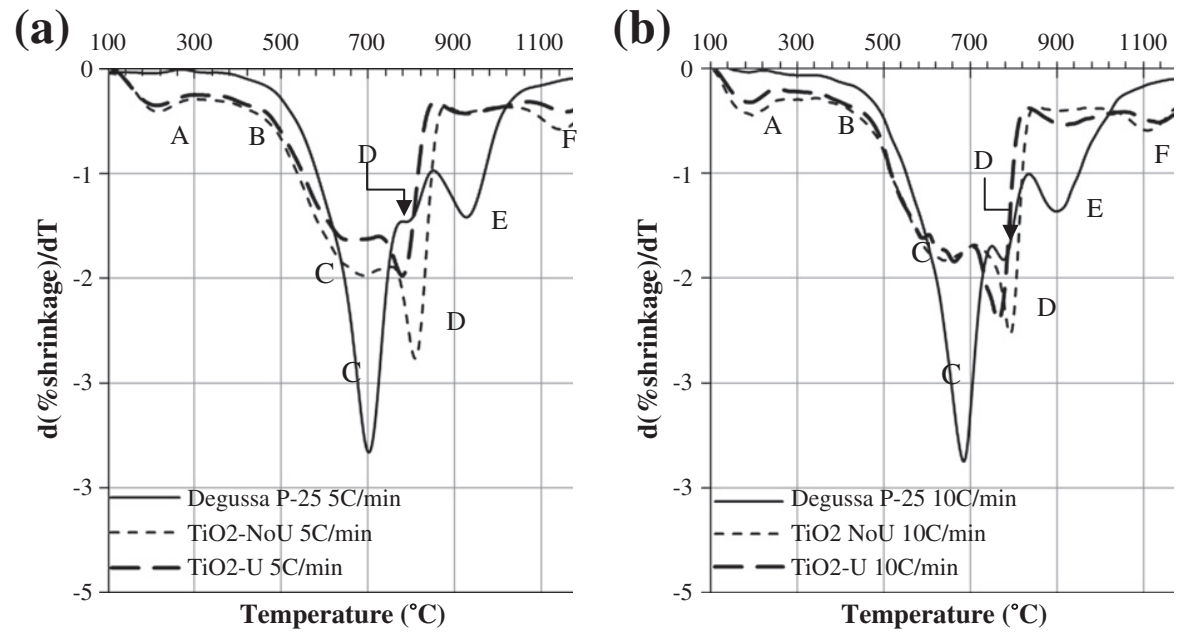

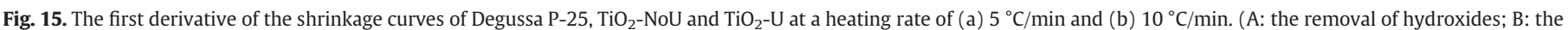

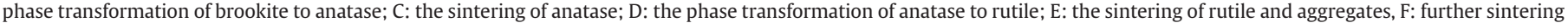
due to the formation of pores between submicron sized densified aggregates).

9 wt.\% for $\mathrm{TiO}_{2}-\mathrm{NoU}$ and $\mathrm{TiO}_{2}-\mathrm{U}$, respectively). The intense and significantly broad peak observed for Degussa P-25 located at $650-700{ }^{\circ} \mathrm{C}$ was attributed to the sintering of anatase (C). The rate of anatase to rutile phase transformation for Degussa P-25 with 13 wt.\% rutile, was not as significant as for both $\mathrm{TiO}_{2}-\mathrm{NoU}$ and $\mathrm{TiO}_{2}-\mathrm{U}$ powder compacts (D). The peaks located at $900{ }^{\circ} \mathrm{C}$ for Degussa $\mathrm{P}-25, \mathrm{TiO}_{2}-\mathrm{NoU}$ and $\mathrm{TiO}_{2}$-U were attributed to the sintering of rutile phase and submicron sized densified aggregates (E). The shrinkage of $\mathrm{TiO}_{2}-\mathrm{NoU}$ and $\mathrm{TiO}_{2}-\mathrm{U}$ powder compacts was still in progress above $1000{ }^{\circ} \mathrm{C}$ which was attributed to further sintering due to the formation of pores between submicron sized densified aggregates $(\mathrm{F})$.

\section{Conclusions}

Nanocrystalline titania powders were prepared by hydrolysis of titanium isopropoxide with or without ultrasonic irradiation at room temperature. The application of ultrasonic irradiation during hydrolysis favors the formation of brookite phase, smaller crystallites, higher surface area/pore volume, and narrower pore size distribution. Pure anatase phase was obtained after heat treatment at $500{ }^{\circ} \mathrm{C}$. The anatase to rutile phase transformation started in the $500-550{ }^{\circ} \mathrm{C}$ range and was completed at $800{ }^{\circ} \mathrm{C}$ for both $\mathrm{TiO}_{2}-\mathrm{NoU}$ and $\mathrm{TiO}_{2}-\mathrm{U}$ powders. The $\mathrm{TiO}_{2}-\mathrm{NoU}$ and $\mathrm{TiO}_{2}-\mathrm{U}$ powders displayed mesoporous structure and indicated the presence of slit shaped pores with high adsorption energy. Commercial Degussa P-25 powder on the other hand was determined to have a macroporous structure. The pore size distribution became wider and the pore volume was reduced by heat treatment which may be related to the collapse of small pores and the formation of larger crystallites hence a coarser pore structure. The presence of $\mathrm{Ti}(\mathrm{OH})_{4}$ was confirmed by FTIR analyses and its transformation to $\mathrm{TiO}_{2}$ upon heating to $200{ }^{\circ} \mathrm{C}$ was detected by TGA analyses. The TGA total weight loss of $\mathrm{TiO}_{2}$-NoU was about $5 \mathrm{wt}$. \% higher than $\mathrm{TiO}_{2}-\mathrm{U}$ powder. The DLS particle size analysis revealed the presence of 25 and $109 \mathrm{~nm}$ nanoparticles (about 97.8 and $2.2 \%$ by number respectively) in the $\mathrm{TiO}_{2}-\mathrm{U}-425$ powder. The dilatometric shrinkage curve of nanotitania has shown a two stage sintering behavior where the former stage may be controlled by small crystallites $(7-10 \mathrm{~nm})$ in the $500-850{ }^{\circ} \mathrm{C}$ range and the latter by aggregates with sizes in submicron range. The phase structure evolution in the powder compacts during sintering was analyzed by the first derivatives of the shrinkage curves which may prove to be very useful for titania based nano material characterization.

\section{References}

[1] M.J. Mayo, M. Ciftcioglu, Issues in the processing of bulk nanocrystalline ceramics for structural applications, in cluster and cluster assembled materials, in: R.S. Averback, P.L. Nelson, J. Bernhole (Eds.), MRS SYmp. Proc., 206, Materials Research Society, Pittsburg, USA, 1991, pp. 545-550.

[2] G.S. Devi, T. Hyodo, Y. Shimizu, M. Egashira, Nanostructured titania $\left(\mathrm{TiO}_{2}\right)$ as hydrogen gas sensor Proc, SPIE 5062 (2003) 106-110.

[3] S.A. Akbar, L.B. Younkman, Ceramic based resistive sensors, Journal of the Electrochemical Society 144 (1997) 1750-1753.

[4] A. Fujishima, K. Honda, Electrochemical photolysis of water at a semiconductor electrode, Nature 238 (1972) 37-38.

[5] K. Hashimoto, H. Irie, A. Fujishima, $\mathrm{TiO}_{2}$ photocatalysis: a historical overview and future prospects, Japanese Journal of Applied Physics 44 (2005) 8269-8285.

[6] F. Han, V.S.R. Kambala, M. Srinivasan, D. Rajarathnam, R. Naidu, Tailored titanium dioxide photocatalysts for the degradation of organic dyes in wastewater treatment: a review, Applied Catalysis A: General 359 (2009) 25-40.

[7] C.A. Countinho, V.K. Gupta, Photocatalytic degradation of methyl orange using polymer-titania microcomposites, Journal of Colloid and Interface Science 333 (2009) 457-464.

[8] D.M. Blake, P.-C. Maness, Z. Huang, E.J. Wolfrum, J. Huang, W.A. Jacoby, Application of the photocatalytic chemistry of titanium dioxide to disinfection and the killing of cancer cells, Separation and Purification Reviews 28 (1999) 1-50.

[9] K.-S. Lin, H.-W. Cheng, W.-R. Chen, C.-H. Wu, Synthesis, characterization, and adsorption kinetics of titania nanotubes for basic dye wastewater treatment, Adsorption 16 (2010) 47-56.

[10] J. Blanco-Galvez, P. Fernandez-Ibanez, S. Malato-Rodrigez, Solar photocatalytic detoxification and disinfection of water: recent overview, Transactions of the ASME 129 (2007) 4-15.

[11] M.F. Dadjour, C. Ogino, S. Matsumura, N. Shimuzu, Kinetics of disinfection of Escherichia coli by catalytic ultrasonic irradiation with $\mathrm{TiO}_{2}$, Biochemical Engineering Journal 25 (2005) 243-248.

[12] J. Zhu, M. Zach, Nanostructured materials for photocatalytic hydrogen production, Current Opinion in Colloid \& Interface Science 14 (2009) 260-269.

[13] D. Gust, D. Kramer, A. Moore, T.A. Moore, W. Vermaas, Engineered and artificial photosynthesis: human ingenuity enters the game, MRS Bulletin 33 (2008) 383-387.

[14] K. Kalyanasundaram, M. Graetzel, Artificial photosynthesis: biomimetic approaches to solar energy conversion and storage, Current Opinion in Biotechnology 21 (2010) 298-310.

[15] M. Faustini, L. Nicole, C. Boissiere, P. Innocenzi, C. Sanchez, D. Grosso, Hydrophobic, antireflective, self-cleaning, and antifogging sol-gel coatings: an example of multifunctional nanostructured materials for photovoltaic cells, Chemistry of Materials 22 (2010) 4406-4413.

[16] X. Chen, S.S. Mao, Titaniumdioxide nanomaterials: synthesis, properties, modifications and applications, Chemical Reviews 107 (2007) 2891-2959.

[17] K. Suslick, Kirk-Othmer Encyclopedia of Chemical Technology, fourth ed. John Wiley and Sons, Inc., New York, 1998.

[18] K. Suslick, G.J. Price, Applications of ultrasound to materials chemistry, Annual Review of Materials Science 29 (1999) 295-326.

[19] Gedanken, Sonochemistry and its application to nanochemistry, Current Science 85 (2003) 1720-1722.

[20] Gedanken, Using sonochemistry for the fabrication of nanomaterials, Sonochemistry 11 (2004) 47-55.

[21] T.J. Mason, J.P. Lorimer, Applied Sonochemistry, Wiley-VCH Verlag GmbH \& Co. KGaA, Weinheim, 2002. 
[22] S.-Y. Kim, T.-S. Chang, C.-H. Shin, Enhancing effects of ultrasound treatment on the preparation of TiO2 photocatalysts, Catalysis Letters 118 (2007) 224-230.

[23] J.C. Yu, J. Yu, W. Ho, L. Zhang, Preparation of highly photocatalytic active nanosized TiO2 particles via ultrasonic irradiation, Chemical Communications (2001) 1942-1943.

[24] C.W. Oh, G.-D. Lee, S.S. Park, C.-S. Ju, S.-S. Hong, Preparation of nanosized $\mathrm{TiO}_{2}$ particles via ultrasonic irradiation and their photocatalytic activity on the decomposition of 4-nitrophenol, Korean Journal of Chemical Engineering 22 (2005) 547-551.

[25] W. Huang, X. Tang, Y. Wang, Y. Koltypin, A. Gedaken, Selective synthesis of anatase and rutile via ultrasound irradiation, Chemical Communications 12 (2000) 1183-1186.

[26] J. Yu, M. Zhou, C. Cheng, H. Yu, X. Zhao, Ultrasonic preparation of mesoporous titanium dioxide nanocrystalline photocatalysts and evaluation of photocatalytic activity, Journal of Molecular Catalysis A: Chemical 227 (2005) 75-80.

[27] J.C. Yu, L. Zhang, J. Yu, Direct sonochemical preparation and characterization of highly active mesoporous TiO2 with a bicrystalline framework, Chemistry of Materials 14 (2002) 4647-4653.

[28] P.S. Awati, S.V. Awate, P.P. Shah, V. Ramaswamy, Photocatalytic decomposition of methylene blue using nanocrystalline anatase titania prepared by ultrasonic technique, Catalysis Communications 4 (2003) 393-400.
[29] Y. Wang, X. Tang, W. Huang, Y.R. Hacohen, A. Gedaken, Sonochemical synthesis of mesoporous titanium oxide withwormhole-like framework structures, Advanced Materials 16 (2000) 1183-1186.

[30] Y.-Q. Wang, S.-G. Chen, Z.-H. Tang, O. Palchik, A. Zaban, Y. Koltypin, A. Gedanken, Mesoporous titanium dioxide: sonochemical synthesis and application in dyesensitized solar cells, Journal of Materials Chemistry 11 (2001) 521-526.

[31] H. Zhang, J.F. Banfield, Understanding polymorphic phase transformation behavior during growth of nanocrystalline aggregates: insights from $\mathrm{TiO}_{2}$, The Journal of Physical Chemistry. B 104 (2000) 3481.

[32] J.B. Condon, Surface Area and Porosity Determinations by Physisorption, Elsevier Publications, Amsterdam, 2006.

[33] F. Rouquerol, J. Rouquerol, K. Sing, Adsorption by Powders and Porous Solids, Academic Press, San Diego, 1999.

[34] J. Yu, S. Liu, H. Yu, Microstructure and photoactivity of mesoporous anatase hollow microspheres fabricated by flüoride-mediated self-transformation, Journal of Catalysis 249 (2007) 59-66.

[35] J. Yu, J.C. Yu, M.K.-P. Leung, W. Ho, B. Cheng, X. Zhao, J. Zhao, Effects of acidic and basic hydrolysis catalysts on the photocatalytic activity and microstructures of bimodal mesoporous titania, Journal of Catalysis 217 (2003) 69-78. 